\title{
Late Deciders in U.S. Presidential Elections
}

\author{
Brian Brox and Joseph Giammo
}

Despite their obvious importance in close elections, previous research into late-deciding voters has come to quite disparate conclusions regarding their traits, attitudes, and behavior. We seek to clear up this confusion through an analysis of late-deciding voters in U.S. Presidential elections from 1988 to 2004. Moving past cursory analyses that treat late deciders as a monolithic group, we divide late deciders by level of interest in the campaign. Low-interest late deciders have few demographic distinctions from other voters but are less connected to and active in politics. They tend to make vote choice decisions based on party identification and issue evaluations. High-interest late deciders look remarkably like those voters who decide earlier in the campaign: politically knowledgeable and attentive to the campaign. They make vote choice decisions based on party identification and evaluations of the economy. Our findings suggest that analyses that fail to account for the two different groups of late deciders risk mischaracterizing their attitudes and behavior.

Over the last several decades, the margins of victory in U.S. presidential elections have been getting smaller (Campbell 2000). As a close race comes to an end, campaigns must spend considerable resources mobilizing their base supporters as well as persuading those remaining voters who have not yet decided for whom they will vote. This situation is best typified by the 2000 presidential election, where the extremely close race in Florida (as well as other close races in Iowa, Minnesota, New Hampshire, New Mexico, Oregon, and Wisconsin) made the behavior of late-deciding voters crucial to determining the overall outcome of the election. But even in 2004, when the national race was less competitive than four years prior, close races in Iowa, New Hampshire, New Mexico, Ohio, Pennsylvania, and Wisconsin forced the campaigns of George W. Bush and John Kerry to fight until Election Day to win the minds of those who were still wavering between the two major party nominees.

In the world of presidential politics, late-deciding voters are an important subset of the electorate. In addition, they are an interesting group of subjects for students of political behavior. Scholars beginning with the Columbia School (Lazarsfeld et al. 1948; Berelson et al. 1954) have con-

\footnotetext{
A previous version of this article was presented at the Annual Meeting of the Southern Political Science Association, November 10, 2001. The authors would like to thank Stephen Medvic, Daron Shaw, John Sides, and the anonymous reviewers for their helpful comments on earlier drafts of this article.
}

BRIAN BROX is Assistant Professor of Political Science at Tulane University and JOSEPH GIAMMO is Assistant Professor of Political Science at the University of Arkansas, Little Rock.

The American Review of Politics, Vol. 30, Winter, 2009-2010: 333-355

(c)2009 The American Review of Politics 
sidered time of decision a key variable in broader studies of electoral behavior. Unfortunately, despite a good deal of work looking at time of decision and the behavior of late-deciding voters in particular, there is no consensus in the literature on what types of people tend to decide late and how they differ demographically and attitudinally from other types of voters. In fact, disagreement exists as to whether late deciders are demographically similar or dissimilar to other types of voters, are engaged in politics or disengaged, use media frequently or infrequently, or vote based on preexisting attitudes or in a more arbitrary fashion.

In this piece we hope to resolve some of these conflicts in the existing literature and to provide additional insight into these voters who have such a significant impact on real world politics. We will begin by looking at the prevalence of late decision-making by voters in U.S. presidential elections from 1988 to 2004. We go on to lay out a theory of why a voter might wait until late in the campaign before deciding how to vote, then look at a large, pooled sample of voters to examine what types of voters tend to decide late and why they put off making a choice among candidates. We conclude by looking at the vote choice decision for late deciders and how their behavior differs from voters who decide before or during the fall campaign.

\section{How Many Decide Late}

The first difficulty in understanding late-deciding voters is determining exactly how many voters decide "late." We define late decision-making as coming to a decision for whom to vote in the two weeks prior to and including Election Day. Early work on time of decision suggested that anywhere from 10 percent (Campbell et al. 1960) to roughly 20 percent (Berelson et al. 1954) of voters in the 1940s and 1950s waited until late in the campaign to decide for whom to vote. Studies of voters in the 1970s and 1980s also produced some differing estimates of how many people decide late. On the high end, Chaffee and Choe (1980) report that roughly 30 percent of voters decided late in the 1976 presidential election. More modestly, Whitney and Goldman (1985) report that only 17 percent of voters decided late in the 1980 presidential election. And in an analysis of voting in presidential elections from 1972 to 1988, Gopoian and Hadjiharalambous (1994) show that late deciders were as much as a quarter of the electorate in the 1976 and 1980 elections while only 13 and 14 percent of the electorate in the 1984 and 1972 elections, respectively.

More recently, many scholars have noted an increase in people deciding late in the campaign (Flanigan and Zingale 1994; Box-Steffensmeier and Kimball 1999; McAllister 2002). In order to test this claim, we use National Election Studies data (Miller et al. 1999a, 1999b; The National Election 
Studies $1996,2000,2004)$ to estimate how many people have been deciding late in presidential elections from 1988 to 2004. In the pooled sample of NES respondents, 20 percent of voters reported deciding in the last two weeks of the campaign. Within that period, the percentage of late deciders fluctuated from a low of 15 percent in 2004 to a high of 24 percent in 1992 (see Appendix). Based on the pooled NES sample, at least one voter in seven will wait until the last two weeks to decide for whom to vote. But contrary to the scholars noted above, there does not appear to be a trend (at least in recent presidential campaigns) of more people deciding late. If anything, there seems to be a growing trend where voters make the decision for whom to vote before the campaign even takes place (i.e., "Decide Before the Fall Campaign"). In any event, our estimates of late deciders are largely in line with those of the previous literature. As a result, it seems clear that even in the high information environment of an American presidential campaign, there are still many voters who do not make up their minds until just before Election Day. By deciding late, these voters have the potential to exert tremendous influence on the outcome of even a moderately close presidential election.

\section{Why They Wait}

It is an interesting puzzle as to why someone would wait until late in the presidential campaign to decide for whom to vote. The timing of a voter's decision is fundamentally linked to his or her vote choice decision, and given what we know about how voters choose among presidential candidates, it is remarkable that even as many as fifteen percent of voters - and possibly more-wait until the last two weeks to decide. Indeed, one would expect that someone with strong partisan attachments would be able to choose his or her preferred candidate as soon as the nomination contests are settled. Similarly, voters choosing among candidates based on ideology or policy positions should be able to learn enough about the candidates throughout the nomination process and during the conventions to allow for a decision relatively early in the campaign. In an age in which coverage of campaigns and of the candidates has become ubiquitous, even those who choose based on the candidates themselves - their charisma, character, experience, or other personal qualities - know these factors as soon as the nominations are settled and receive enough reinforcing information throughout the late summer and early fall to make possible a decision before the last minute.

Yet many do decide late. There are two possible explanations for such behavior. On one hand, it is possible that late deciding voters put off the vote choice decision because they do not have enough information about the 
candidates to make a choice. As we just noted, the contextual factors (state of the economy, war and peace, stay-the-course vs. change dynamic), partisanship and policies, and character of the candidates are well-known and well-covered by the media throughout the summer and fall of the election year, so for voters not to know anything about the candidates that can help them choose suggests they just are not paying attention. Thus, one reason for late-decision-making could be that people with little or no interest in politics wait to learn about the candidates until the calendar essentially forces them to do so.

The other possibility is that late deciding voters put off the vote choice decision because they do not feel that they know enough about the candidates. In contrast to their inattentive peers, these late-deciding voters probably have been paying attention to the campaign, know the candidates and their partisanship, issues, and personal qualities, and still remain unconvinced. By delaying the decision until the last minute, these late deciders allow the campaign to take its course, gathering as much information as possible before Election Day itself forces them to make a choice. This suggests that they either feel a responsibility to wait until all of the evidence is in or that the information that they do possess does not clear up the choice for them. If, for example, a voter thoroughly researched issue positions of both candidates in the presidential election on the most important issues to her and found each candidate agreed with her on half of them, she could reasonably have a difficult time making a choice, without implying apathy or ignorance.

As a result, we believe there are two types of individuals predisposed to decide late in the campaign: those uninterested in the campaign who, for some reason, decide to participate at the last minute and must therefore make a vote choice decision right before Election Day, and those voters who are interested in the campaign and attempt to gather as much information as possible before choosing their preferred presidential candidate. We further believe that these two types of individuals are different from each other (and from those who decide earlier in the campaign) with respect to demographic and attitudinal traits as well as with respect to the factors that affect their vote choice decisions. Unfortunately, much previous research on late deciders fails to account the possibility of two types of late deciders, and as a result there is considerable confusion about who decides late in the campaign and how they make their vote choice decisions. But before we turn to our own analysis of late deciders, we first review what previous research has said about them, noting that failure to account for the two possible rationales for late decision-making often leads to inconclusive findings. 


\section{Who Decides Late}

Given their numbers, one would think scholars would have a good understanding of what kinds of people tend to decide late. Unfortunately, this is not the case. Substantial disagreement exists concerning the demographic, attitudinal, and behavioral traits of late-deciding voters. Demographically, Gopoian and Hadjiharalambous (1994) report that late-deciding voters tend to be younger than voters who decide earlier in the campaign. They also show that higher social status (as expressed through race and education) occasionally correlates with deciding late. This latter finding, however, is contradicted by both Chafee and Choe (1980) and Whitney and Goldman (1985), who show that "voters with above-average levels of income and education had made up their minds earlier than others" (Whitney and Goldman 1985, 519).

With respect to political attitudes, there is a bit more agreement (or at least lack of disagreement) regarding the traits of late deciders. Late-deciding voters tend to have weaker party identification, see fewer differences between the parties, have less interest in politics, care little about election outcomes (Gopoian and Hadjiharalambous 1994), and tend to be less politically sophisticated (Campbell et al. 1960; Gopoian and Hadjiharalambous 1994).

Finally, the political behavior literature has not been able to come to a consensus on the behavioral traits of late-deciding voters. While some believe that late deciders tend to be less politically involved (Kessel 1968; Gopoian and Hadjiharalambous 1994), McAllister (2002) argues that only a subset of late deciders can be so characterized, and that other late-deciding voters (dubbed "rational") tend to be more involved in politics. Media consumption is another unresolved issue. Gopoian and Hadjiharalambous (1994) show that media usage for late deciders is no different than for other types of voters while Chafee and Choe (1980) argue that late deciders consume less media and Whitney and Goldman (1985) argue that they consume more. Perhaps most importantly, scholars do not have a firm grip on the factors that motivate the voting decisions of late deciders. Chafee and Choe (1980) and Campbell (2000) argue that late deciders vote based on their party identification while Markus (1982) suggests that party identification (as well as candidate evaluations) does not explain voting well for late deciders. Gopoian and Hadjiharalambous (1994) go so far as to say that candidate choice decisions among late-deciding voters "appear nearly random in nature" (p. 76).

With an eye toward resolving some of the confusion regarding the traits of late-deciding voters, we estimate a binomial logistic regression model that predicts time of decision. The dependent variable is coded one if the respon- 
dent decided for whom to vote during the last two weeks of the campaign and zero otherwise. ${ }^{1}$ For independent variables, we include several measures of respondent demographic, attitudinal, and behavioral traits for which there is disagreement in the previous literature on late deciders. We also include several campaign-specific variables (to assess the impact of context on time of decision) as well as a control variable for gender and dummy variables for the year of each election. We estimate this model on pooled National Election Studies data from 1988 to 2004. The results of this analysis are presented in Table 1.

If the view that all late deciders are simply uninformed, apathetic, and inattentive is correct, then we should find important differences between those who decide early and those who decide late on a host of these controls. In terms of the demographic variables, we would expect that late deciders should be younger, less educated, and have lower average incomes than those who decide early. Each of these would be consistent with that generally negative view and is reflected in the findings of at least one of the works cited above. Similarly, we would expect the attitudinal variables included in the model to be related to time of decision, with those deciding late demonstrating a weaker party identification, being less likely to see a difference between the candidates, having less interest in the election, caring less who wins, knowing less about politics, and reporting smaller differences in their thermometer ratings of the two candidates. The behavioral variables would also be significant predictors of time of decision, with late deciders being less politically active and less likely to pay attention to media coverage of the election.

One thing not discussed in the previous literature, however, is the impact of context on time of decision. If both campaigns are making a concerted effort to win over voters in a given state, people in that state will be bombarded with arguments in favor of both candidates, which should make choosing a candidate more difficult. Therefore, we include two sets of measures of campaign activity. First, in order to measure how one-sided or balanced the information coming from the campaigns is, we include variables measuring the absolute difference between the Democratic and Republican presidential candidates advertising in the state, ${ }^{2}$ the number of appearances by the candidates, ${ }^{2}$ and the campaigns' own battleground rankings of the state. ${ }^{3}$ The closer these measures are to zero, the greater the chance that voters are receiving balanced information overall. We also control for the combined advertising, campaign appearances, and battleground ratings of the two campaigns. While more balanced information should make a decision more difficult to make, the overall amount of that information could also make a difference. A voter in Florida and a voter in New York may have received equally balanced information during the election, however, 
Table 1. Predicting Time of Decision

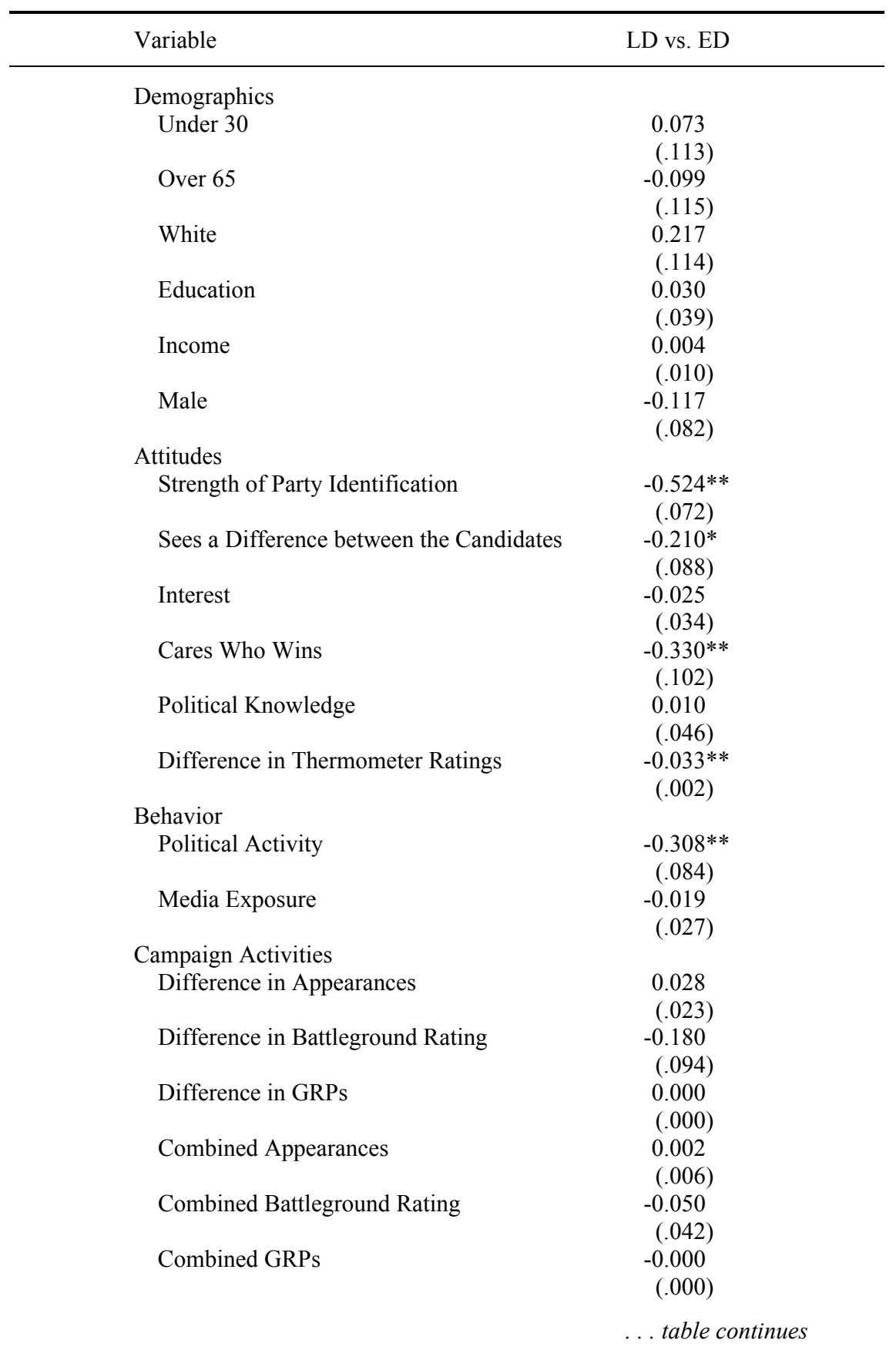


Table 1. Predicting Time of Decision (continued)

\begin{tabular}{cc}
\hline Variable & LD vs. ED \\
\hline Election Year & $0.534^{* *}$ \\
1992 & $(.122)$ \\
1996 & 0.234 \\
2000 & $(.164)$ \\
& $-0.463^{* *}$ \\
2004 & $(.151)$ \\
& $0.408^{* *}$ \\
Constant & $(.187)$ \\
& 0.364 \\
Number of Cases & $(.242)$ \\
Pseudo $\mathrm{R}^{2}$ & 4872 \\
Cells are binomial logistic regression coefficients and (standard errors). & \\
$* * \mathrm{p}<.01 ; * \mathrm{p}<.05$ & \\
\hline
\end{tabular}

the voter in Florida received far more information overall. Given that greater amount of information, the voter in Florida is probably more likely to delay his decision than the voter in New York, who is essentially given no reason directly by either campaign to choose one or the other.

In comparing late deciders to those who decide earlier in the race, we see that late deciders are less partisan, less likely to see a difference between the candidates, less likely to care who wins, less likely to give one candidate a higher thermometer rating score than the other, and less likely to be politically active. These findings support many of the findings presented in studies of the political attitudes of late deciders, and conform to the picture of those who put off their decision about which candidate to support as being relatively uninformed, uninvolved, and apathetic when compared to those coming to a decision sooner.

Despite these notable differences between late deciders and other voters, perhaps the most important finding in Table 1 is how many variables do not seem to differentiate these two groups. Late deciders are not demographically distinct from early deciders. They are also not more or less likely to live in states in which the balance of campaign information makes coming to a conclusion more difficult, nor in states in which they receive more or less information from the campaigns overall. Furthermore, the groups are not differentiated by their interest in the campaign, their political knowledge, or their exposure to the media. These finding clearly do not fit with that same negative image of late deciders. 
While these results, therefore, do little to clear the confusion present in the previous literature, this lack of significant differentiation may suggest that late deciders are not the monolithic group that much of the previous literature (save McAllister) has made them out to be. The coefficients for all of the variables related to political knowledge and attention to politics (interest in the campaign, media exposure) would be statistically insignificant if late deciders were truly indistinguishable from campaign deciders and precampaign deciders. However, real differences might be hidden if there are actually two distinct types of late deciders - apathetic voters who do not pay any attention to the campaign until it is almost too late, and well informed late deciders who feel that they need to wait until all the evidence is in before making a decision. While we might search for this distinction in several different areas, the most logical place to find it is in their interest in the campaign. What should clearly differentiate the apathetic from the involved is their level of interest. In fact, at this point it would be useful to consider more formally McAllister's (2002) efforts to divide late deciders into distinct groups - one that is more connected to politics and another that is less connected. McAllister dubs the former group "rational" and notes that rational late deciders care more about politics are more likely to participate in political activities, and tend to pay more attention to the media. In contrast, "capricious" late deciders are less likely to participate in political activities, have less interest in politics, and tend to pay little attention to the media.

McAllister's (2002) typology is based on an analysis of National Election Studies data from 1996. If his division of late deciders into two distinct groups holds more generally for voters over several presidential elections, then that would go a long way to resolving some of the obvious disagreements in the previous literature. As discussed above, some studies show late deciders as engaged, interested, and participatory while others see them as disengaged, uninterested, and unlikely to participate in politics. ${ }^{4}$ And regarding voting behavior, some come to the conclusion that standard models of voting do not work well for late deciders while others suggest partisanship is what drives their vote choice decisions. ${ }^{5}$ Yet many of these studies are limited to one or two elections and are based on relatively small, geographically concentrated samples. It is possible that these studies are drawing on only one type of late-deciding voter. The two national, large-N studies of late deciders (Gopoian and Hadjiharalambous 1994; McAllister 2002) do little to clarify the situation, as they come to differing conclusions about the character and behavior of these voters.

If late deciders can be separated into distinct groups, as we argue they should, then it would be possible to describe them more clearly, both in terms of their demographic and attitudinal traits as well as their voting (and 
related) behavior. By dividing the subsample of late deciders into two groups, we are suggesting two disparate rationales for waiting until late in the campaign to decide for whom to vote. The first rationale is based on a view of a late-decider as the stereotypical apathetic citizen. This person is not interested in politics, and thus may not be aware of the campaign or the fact that there is a choice to be made among presidential candidates until right before Election Day. The other rationale for late decision-making is based on the view of an attentive citizen who feels he or she has the duty to hear both candidates present their views, and is likely to wait until the end of the campaign to make up his or her mind as to which candidate is best. These more highly-interested late deciders are more likely to see a difference between the candidates, care who wins, be politically active, and pay more attention to the media.

We argue that the interest variable serves as a good discriminator between the two type types of late deciders. Since our theoretical expectation is that the distinction between these two groups is that one is relatively apathetic, while the other is attentive, but reserving judgment, interest should be the best way to separate the groups. Furthermore, interest is itself an important influence on a number of important behavioral variables. For the average respondent in the pooled NES sample, as interest in the campaign increases, the respondent's political information increases, (s)he sees more differences between the candidates, (s)he is more active in the campaign, (s)he cares more about who wins, and (s)he has higher exposure to the media. Furthermore, we expect that these two groups would differ in the related attitudinal and behavioral measures. Specifically, we expect that lowinterest late deciders (LILDs) have weaker party identification, see fewer differences between the candidates, care less about who wins, have lower political sophistication, are less politically active, and are exposed to less media than high-interest late deciders (HILDs), as well as those who decide earlier in the campaign.

With this new division of the sample, ${ }^{6}$ we make use of a series of binomial logistic regression model that provides for direct comparisons between the two groups of late deciders, as well as between each of these groups and those deciding earlier. As before, we use measures of respondent demographic, attitudinal, and behavioral traits as explanatory variables, as well as context variables and controls for gender and dummy variables for the years. Again, we estimate this model on pooled National Election Studies data from 1988 to 2004 . The results of this analysis are presented in Table 2.

As expected, LILDs and HILDs differ along a number of dimensions, with at least one significant difference in each of the four types of variables we considered. LILDs and HILDs differ along one demographic dimension, 
Table 2. Predicting Time of Decision-Late Deciders Split

\begin{tabular}{|c|c|c|c|}
\hline Variable & $\begin{array}{l}\text { LILD vs. } \\
\text { HILD }\end{array}$ & $\begin{array}{l}\text { LILD vs. } \\
\text { ED }\end{array}$ & $\begin{array}{l}\text { HILD vs. } \\
\text { ED }\end{array}$ \\
\hline \multicolumn{4}{|l|}{ Demographics } \\
\hline Under 30 & $\begin{array}{r}-0.107 \\
(.235)\end{array}$ & $\begin{array}{l}0.009 \\
(.130)\end{array}$ & $\begin{array}{l}0.216 \\
(.186)\end{array}$ \\
\hline Over 65 & $\begin{array}{c}-0.351 \\
(.224)\end{array}$ & $\begin{array}{r}-0.215 \\
(.140)\end{array}$ & $\begin{array}{l}0.116 \\
(.170)\end{array}$ \\
\hline White & $\begin{array}{l}0.748^{* *} \\
(.242)\end{array}$ & $\begin{array}{l}0.427 * * \\
(.140)\end{array}$ & $\begin{array}{c}-0.090 \\
(.172)\end{array}$ \\
\hline Education & $\begin{array}{c}-0.074 \\
(.058)\end{array}$ & $\begin{array}{l}0.011 \\
(.034)\end{array}$ & $\begin{array}{l}0.062 \\
(.045)\end{array}$ \\
\hline Income & $\begin{array}{c}0.014 \\
(.017)\end{array}$ & $\begin{array}{l}0.006 \\
(.010)\end{array}$ & $\begin{array}{l}0.001 \\
(.014)\end{array}$ \\
\hline Male & $\begin{array}{c}-0.058 \\
(.167)\end{array}$ & $\begin{array}{c}-0.196^{*} \\
(.097)\end{array}$ & $\begin{array}{l}0.014 \\
(.128)\end{array}$ \\
\hline \multicolumn{4}{|l|}{ Attitudes } \\
\hline Strength of Party Identification & $\begin{array}{c}-0.112 \\
(.143)\end{array}$ & $\begin{array}{c}-0.512 * * \\
(.087)\end{array}$ & $\begin{array}{c}-0.546^{* *} \\
(.114)\end{array}$ \\
\hline Sees a Difference between the Candidates & $\begin{array}{c}-0.713 * * \\
(.177)\end{array}$ & $\begin{array}{c}-0.339^{* *} \\
(.101)\end{array}$ & $\begin{array}{l}0.199 \\
(.152)\end{array}$ \\
\hline Interest & - & - & - \\
\hline Cares Who Wins & $\begin{array}{c}-1.020 * * \\
(.215)\end{array}$ & $\begin{array}{c}-0.515^{* *} \\
(.111)\end{array}$ & $\begin{array}{l}0.316 \\
(.192)\end{array}$ \\
\hline Political Knowledge & $\begin{array}{c}-0.259 * * \\
(.099)\end{array}$ & $\begin{array}{c}-0.033 \\
(.054)\end{array}$ & $\begin{array}{l}0.117 \\
(.078)\end{array}$ \\
\hline Difference in Thermometer Ratings & $\begin{array}{c}-0.006 \\
(.004)\end{array}$ & $\begin{array}{c}-0.036^{* *} \\
(.003)\end{array}$ & $\begin{array}{c}-0.030^{* *} \\
(.003)\end{array}$ \\
\hline \multicolumn{4}{|l|}{ Behavior } \\
\hline Political Activity & $\begin{array}{c}-0.461 * * \\
(.164)\end{array}$ & $\begin{array}{c}-0.498 * * \\
(.100)\end{array}$ & $\begin{array}{c}-0.031 \\
(.130)\end{array}$ \\
\hline Media Exposure & $\begin{array}{c}-0.418 * * \\
(.055)\end{array}$ & $\begin{array}{c}-0.131 * * \\
(.032)\end{array}$ & $\begin{array}{l}0.210^{* *} \\
(.043)\end{array}$ \\
\hline \multicolumn{4}{|l|}{ Campaign Activities } \\
\hline Difference in Appearances & $\begin{array}{l}0.125^{*} \\
(.049)\end{array}$ & $\begin{array}{l}0.052 \\
(.027)\end{array}$ & $\begin{array}{c}-0.025 \\
(.038)\end{array}$ \\
\hline Difference in Battleground Rating & $\begin{array}{c}-0.231 \\
(.191)\end{array}$ & $\begin{array}{r}-0.217 \\
(.112)\end{array}$ & $\begin{array}{r}-0.108 \\
(.147)\end{array}$ \\
\hline Difference in GRPs & $\begin{array}{r}-0.000 \\
(.000)\end{array}$ & $\begin{array}{l}0.000 \\
(.000)\end{array}$ & $\begin{array}{l}0.000 \\
(.000)\end{array}$ \\
\hline Combined Appearances & $\begin{array}{c}-0.318^{*} \\
(.014)\end{array}$ & $\begin{array}{c}-0.003 \\
(.007)\end{array}$ & $\begin{array}{l}0.016 \\
(.010)\end{array}$ \\
\hline Combined Battleground Rating & $\begin{array}{l}0.025 \\
(.091)\end{array}$ & $\begin{array}{r}-0.013 \\
(.049)\end{array}$ & $\begin{array}{r}-0.084 \\
(.066)\end{array}$ \\
\hline Combined GRPs & $\begin{array}{l}0.000 \\
(.000)\end{array}$ & $\begin{array}{c}-0.000 \\
(.000)\end{array}$ & $\begin{array}{c}-0.000 \\
(.000)\end{array}$ \\
\hline
\end{tabular}


Table 2. Predicting Time of Decision-Late Deciders Split

\begin{tabular}{lccc}
\hline Variable & $\begin{array}{c}\text { LILD vs. } \\
\text { HILD }\end{array}$ & $\begin{array}{c}\text { LILD vs. } \\
\text { ED }\end{array}$ & $\begin{array}{c}\text { HILD vs. } \\
\text { ED }\end{array}$ \\
\hline Election Year & & & \\
1992 & -0.365 & $0.344^{*}$ & $0.749^{* *}$ \\
& $(.254)$ & $(.145)$ & $(.196)$ \\
1996 & 0.247 & 0.281 & -0.042 \\
& $(.377)$ & $(.188)$ & $(.304)$ \\
2000 & 0.131 & $0.417^{*}$ & 0.475 \\
& $(.310)$ & $(.178)$ & $(.245)$ \\
2004 & 0.523 & $0.499^{* *}$ & 0.015 \\
& $(.341)$ & $(.181)$ & $(.258)$ \\
Constant & $4.485^{* *}$ & $0.705^{*}$ & $-3.058^{* *}$ \\
& $(.534)$ & $(.281)$ & $(.407)$ \\
Number of Cases & & 4573 & 4204 \\
Pseudo $\mathrm{R}^{2}$ & .194 & .197 & .116 \\
Cells are multinomial logistic regression coefficients and (standard errors). & \\
$* * \mathrm{p}<.01 ;{ }^{*} \mathrm{p}<.05$ & & & \\
\hline
\end{tabular}

with LILDs more likely to be white. Given the large majority of African American voters who consistently identify with the Democratic Party, this should not be surprising. There are several attitudinal differences between the groups. LILDs are less likely to see differences between the candidates, to care who wins the election, or to know a lot about politics in general. These attitudinal differences also show up in their behavior, where they are less likely to be involved in politics in ways other than voting and less likely to pay attention to the news. So, not surprisingly, we find that, when broken up by interest, LILDs know less, get less involved, and care less about the election. They very neatly conform to the expectation that at least some late deciders are making a choice so close to the election simply because they have not thought about it before then. The statistically significant campaign variables are interesting, but the first is counter-intuitive. LILDs are more likely to live in a state in which there is a disparity in the number of times that the presidential candidates visited that state. So, in at least one facet of the campaign, these voters are getting more of a one-sided picture, yet still not coming to a conclusion. The second, however, fits more neatly with our expectations. The more combined visits by the presidential candidates, the less likely that those deciding late will fall into the low interest category. This is much more intuitive, since the more total visits that a state receives from candidates, the more likely it would be that some aspect of the 
campaign would break through potential voters' apathy and cause them to make a choice.

While the results from the first version of the model support the generally negative view of LILDs, the same results would be found if HILDs were simply extraordinary in their attention, knowledge, etc., so it helps to also compare LILDs to a third group - those who decide early (EDs). Here we find that there are still differences in demographics, attitudes, and behavior, but that the campaign variables disappear. Since many EDs make a decision before the campaign even begins, it is not surprising that nothing about the campaign itself explains the time of decision in this comparison. Looking at the other variables, though, there are several similarities to the results in the comparison between different types of late deciders. When compared to those deciding earlier, LILDs are still more likely to be white, less likely to see a difference between the candidates, less likely to care who wins, less politically active, and less likely to be paying attention to the media. There are also, however, differences which did not show up in the first comparison. LILDs are less likely to be men, less partisan, and less likely to have differences in thermometer ratings. Unlike the comparison with HILDs, on the other hand, they are no different in their levels of political knowledge. So, the negative image holds up - to a point. Compared to those who decide early, LILDs care less and get less involved in politics, but they do not know less about politics than those who decide early. Instead, they are simply less likely to be attached strongly to a party and, presumably therefore, less likely to be motivated to choose by the information that they do have.

The first thing that stands out about the final comparison is how few differences there are. HILDS are no different from EDs on the demographic or campaign variables, and, in fact, only differ significantly from them along three variables (excluding the 1992 dummy variable) - partisan intensity, differences in thermometer ratings, and media exposure. While the differences in the first two are in the same direction as the differences between LILDs and EDs (less partisan and less likely to rate the candidates differently on a thermometer scale), HILDs are actually more likely to pay attention to the media. So, compared to those deciding sooner, HILDs are no less likely to see a difference, care who wins, or get involved in politics, and they are in fact more likely to pay attention to news coverage of the campaign. These, then are people who are as aware and involved as the people deciding sooner, but do not feel as great an attachment to either of the parties, and, not surprisingly, are less likely to have strong feelings for one candidate over the other. In fact, that combination suggests that the problem is not that they do not know enough about the candidates to make a choice, which may well be the case with LILDs, but that instead the differences they see between the 
candidates are not the ones that they care enough about to lead them to a choice.

Looking across all three, then, it is possible to make some assertions about which differences are related to deciding late in and of itself and which differences are linked to the level of interest. Those deciding late are less partisan and less likely to give different thermometer ratings for the candidates, regardless of their interest in the campaign. Differences in demographics, in seeing a difference between the candidates, caring who wins, political activity, and media exposure, however, are more directly linked to the level of interest.

These findings support the idea that late deciders are far from being a uniform group. Low-interest late deciders are distinct from high-interest late deciders as well as those who decide earlier in the campaign on a number of key variables, particularly those related to political attitudes and behavior that affect vote choice. It is to an analysis of vote choice that we now turn. We seek to show how the two groups of late deciders - distinguished by level of interest - differ in the way the come to choose for whom to vote. As a reference, we include those who decide earlier in the campaign in the analysis.

\section{How Late Deciders Vote}

Analyses of the voting behavior of late deciders have produced some inconclusive findings. Some suggest that late deciders are more likely to use partisanship as a cue when casting a ballot. Campbell (2000) finds that late deciders, once they have made the decision to turnout, tend to gravitate toward their party's candidate, especially if that candidate is trailing. Campbell finds that seven out of ten late-deciding Democrats and eight out of ten late-deciding Republicans vote for their party's candidate. Campbell's result mirrors findings by Whitney and Goldman (1985) and Chaffee and Choe (1980) who find (though not as strongly) that late deciders vote based on partisanship. Others, however, argue that voters who decide late in the campaign are less committed to political parties (Fournier et al. 2004) and are more likely to respond to actual campaign events and coverage (Fournier et al. 2004; Box-Steffensmeier and Kimball 1999). Most perplexing, however, are the findings of Gopoian and Hadjiharalambous (1994). They find that late-deciding voters defect from their party more frequently (contrary to Campbell, Whitney and Goldman, and Chaffee and Choe) and, in essence, "behave in a near-random fashion in casting votes for president" (p. 58).

It would be useful to clear up this confusion and to develop a better understanding of how late deciders choose between the candidates, especially given that in close races, it is these voters that may determine the 
outcome of the election. Again, external factors could be the driving force behind their final choices. The mobilization and persuasion efforts of the campaign could very conceivably affect these late deciders. As parties and candidates become more adept at identifying and targeting voters, it would only make sense that they would intensify their efforts on those voters who might still be undecided late in the campaign. Therefore, campaign spending, mobilization activities, and advertising should affect the decisions of those late deciders who are paying attention.

If these voters are simply inattentive before the fall, however, external events may be much less important, except as they serve to activate latent preferences. For example, it may be that a voter who does not tune into the race until October will be quickly reassured that his party's nominee really does favor the party's traditional issues and constituencies, and therefore will move in the direction that his partisanship would predict. Other characteristics which are correlated with the parties' traditional issue stands, such as income, race, and gender, should therefore serve as predictors of vote choice for low-interest late deciders.

In order to look at the voting behavior of late-deciding voters, we estimate a series of binomial logistic regression models that predicts vote choice. In each model, the dependent variable is coded zero if the respondent voted for the Democratic presidential candidate and coded one if the responded voted for the Republican. For independent variables, we include several behavioral and demographic measures as well as measures of campaign efforts. ${ }^{7}$ We estimate this model separately for low interest late deciders, high interest late deciders, and those who decide earlier in the campaign using pooled National Election Studies data from 1988 to 2004 . $^{8}$ The results of these analyses are presented in Table 3.

Among low-interest late deciders, four features, encompassing attitudinal, demographic, and campaign variables, seem to influence the choice among presidential candidates: party identification, issues, race, and television advertising. The influence of party identification is not surprising, given that much of the previous literature found this to be the case (Campbell 2000; Whitney and Goldman 1985; Chaffee and Choe 1980). The fact that white low-interest late deciders tend to vote Republican and/or minority low-interest late deciders tend to vote Democratic is also not unexpected, given the traditional alignment of each party with those respective racial groups.

Significantly more interesting is the fact that issues appear to motivate the voting behavior of these voters. We do not argue that low-interest late deciders are intensely scrutinizing candidate statements and party platforms to see which candidate matches their issue preferences. Instead, we believe that since the issue positions of the presidential candidates are typically 
Table 3. Predicting Vote Choice

\begin{tabular}{|c|c|c|c|}
\hline Variable & LILD & HILD & ED \\
\hline \multicolumn{4}{|l|}{ Demographics } \\
\hline Income & $\begin{array}{l}0.003 \\
(.020)\end{array}$ & $\begin{array}{l}0.036 \\
(.032)\end{array}$ & $\begin{array}{l}0.048 * * \\
(.014)\end{array}$ \\
\hline White & $\begin{array}{l}0.918 * * \\
(.333)\end{array}$ & $\begin{array}{l}0.368 \\
(.434)\end{array}$ & $\begin{array}{l}1.097 * * \\
(.187)\end{array}$ \\
\hline Male & $\begin{array}{l}0.222 \\
(.186)\end{array}$ & $\begin{array}{l}0.177 \\
(.318)\end{array}$ & $\begin{array}{r}-0.257^{*} \\
(.124)\end{array}$ \\
\hline Education & $\begin{array}{l}0.063 \\
(.063)\end{array}$ & $\begin{array}{c}-0.040 \\
(.102)\end{array}$ & $\begin{array}{c}-0.034 \\
(.041)\end{array}$ \\
\hline Union Household & $\begin{array}{c}-0.256 \\
(.231)\end{array}$ & $\begin{array}{l}0.483 \\
(.398)\end{array}$ & $\begin{array}{c}-0.549 * * \\
(.256)\end{array}$ \\
\hline \multicolumn{4}{|l|}{ Attitudes } \\
\hline Party Identification & $\begin{array}{l}0.409 * * \\
(.055)\end{array}$ & $\begin{array}{l}0.491 * * \\
(.093)\end{array}$ & $\begin{array}{l}1.102 * * \\
(.037)\end{array}$ \\
\hline Issue Distance to the & $-0.176^{* *}$ & -0.069 & $-0.241 * *$ \\
\hline Republican Candidate & $(.049)$ & $(.074)$ & $(.031)$ \\
\hline Issue Distance to the & 0.094 & 0.117 & $0.331 * *$ \\
\hline Democratic Candidate & $(.053)$ & $(.086)$ & $(.035)$ \\
\hline Economic Evaluation & $\begin{array}{l}0.132 \\
(.100)\end{array}$ & $\begin{array}{l}0.349^{*} \\
(.157)\end{array}$ & $\begin{array}{l}0.644 * * \\
(.067)\end{array}$ \\
\hline \multicolumn{4}{|l|}{ Campaign Activities } \\
\hline Contacted by the Republican Party & $\begin{array}{l}0.237 \\
(.250)\end{array}$ & $\begin{array}{l}0.229 \\
(.368)\end{array}$ & $\begin{array}{r}-0.134 \\
(.150)\end{array}$ \\
\hline Contacted by the Democratic Party & $\begin{array}{l}0.063 \\
(.231)\end{array}$ & $\begin{array}{l}0.097 \\
(.333)\end{array}$ & $\begin{array}{c}-0.103 \\
(.148)\end{array}$ \\
\hline Appearances by the & 0.030 & -0.019 & -0.008 \\
\hline Republican Candidate & $(.033)$ & $(.061)$ & $(.023)$ \\
\hline Appearances by the & -0.043 & 0.033 & 0.001 \\
\hline Democratic Candidate & $(.033)$ & $(.056)$ & $(.021)$ \\
\hline Republican Presidential Ads & $\begin{array}{c}-0.168^{*} \\
(.071)\end{array}$ & $\begin{array}{l}0.101 \\
(.113)\end{array}$ & $\begin{array}{l}0.075 \\
(.046)\end{array}$ \\
\hline Democratic Presidential Ads & $\begin{array}{l}0.167^{*} \\
(.067)\end{array}$ & $\begin{array}{c}-0.140 \\
(.108)\end{array}$ & $\begin{array}{c}-0.084 \\
(.045)\end{array}$ \\
\hline Republican Candidate's & 0.196 & -0.029 & -0.227 \\
\hline Battleground Rating of the State & $(.226)$ & $(.414)$ & $(.147)$ \\
\hline Democratic Candidate's & -0.143 & -0.033 & 0.204 \\
\hline Battleground Rating of the State & $(.196)$ & $(.377)$ & $(.128)$ \\
\hline \multicolumn{4}{|l|}{ Election Year } \\
\hline 1992 & $\begin{array}{l}0.713 \\
(.338)\end{array}$ & $\begin{array}{c}-0.396^{*} \\
(.556)\end{array}$ & $\begin{array}{l}0.101 \\
(.218)\end{array}$ \\
\hline 1996 & $\begin{array}{l}0.058 \\
(.313)\end{array}$ & $\begin{array}{c}-0.526 \\
(.645)\end{array}$ & $\begin{array}{c}-0.864 * * \\
(.217)\end{array}$ \\
\hline 2000 & $\begin{array}{l}0.500 \\
(.400)\end{array}$ & $\begin{array}{c}-0.690 \\
(.650)\end{array}$ & $\begin{array}{l}0.430 \\
(.263)\end{array}$ \\
\hline
\end{tabular}


Table 3. Predicting Vote Choice (continued)

\begin{tabular}{lccc}
\hline Variable & LILD & HILD & ED \\
\hline Election Year (continued & & & \\
2004 & $0.967^{* *}$ & 0.108 & 0.266 \\
& $(.378)$ & $(.625)$ & $(.234)$ \\
Constant & $-2.820^{* *}$ & $-3.290^{* *}$ & $-6.596^{* *}$ \\
& $(.595)$ & $(.982)$ & $(.403)$ \\
Number of Cases & 645 & 270 & 4334 \\
Pseudo $\mathrm{R}^{2}$ & .1760 & .2336 & .6838 \\
Cells are binomial logistic regression coefficients and (standard errors). & \\
$* * \mathrm{p}<.01 ; * \mathrm{p}<.05$ & & \\
\hline
\end{tabular}

strongly correlated with the traditional positions of their parties, people who are not paying much attention to the campaign can make a reasonable guess about each candidate's issue preferences and choose accordingly.

The campaign also appears to influence low-interest late deciders, but in an unexpected fashion. As they are exposed to more Republican television advertisements, they are less likely to vote Republican, and as they see more Democratic advertisements, they are more likely to vote Republican, with a magnitude in each case that is surprisingly large. Holding other values to their means, an increase from one standard deviation below the mean level of Republican ads in a state to one standard deviation above the mean level decreases the probability that a low-interest late decider will vote for the Republican candidate from about an 80 percent probability to about a 40 percent probability. There is an almost equally large impact for the same change in Democratic advertising. While we have no certain explanation for this result, there are some possibilities. First, these voters may actually be likely to become irritated with the efforts of candidates to attract their votes, since we know that they have little interest in the campaign in the first place. Second, while our model does not attempt to control for type of ads, it is reasonable to expect that large scale advertising blitzes in a state will be likely to contain a significant portion of negative ads, particularly given that states in which candidates spend a lot of advertising dollars are, of course, overwhelmingly the most competitive states. Candidates should have a greater incentive in those states to attack each other, since any marginal gain in support can make a difference in who wins that state's electoral votes. Since these voters are less partisan than their counterparts, they should be more turned off by negative advertising than other voters (Ansolabehere and Iyengar 1995). 
Among high-interest late deciders, the list of influential factors is much shorter, and in fact only includes attitudinal variables. These voters seem to choose among candidates based on party identification and evaluations of the economy. The influence of party identification is slightly stronger among these late deciders than among those with lower interest. Moving across the range of values of party identification increases the probability of voting for the Republican candidate by over 60 percentage points for high-interest late deciders, as compared to about 50 percentage points for low-interest late deciders. Yet the influence of party identification among late deciders of any interest level conforms to much of the previous literature. What is more interesting is that high-interest late deciders, contrary to their low-interest counterparts, make vote choice decisions based on evaluations of the economy rather than assessments of the issue positions of the candidates. An uninformed voter (in this case a low-interest late decider) would seem to be most likely to evaluate economic conditions based on the best evidence reaily at hand: their own personal economic conditions. Over a large sample of low-interest late deciders, this would introduce a great deal of variability in the measure, particularly because actual economic conditions are far more variable than the parties' positions on issues. On the other hand, highinterest late deciders should be far more likely to give economic evaluations that are correlated with actual national economic conditions (particularly given that we know they pay more attention to the media). As a result, assessments of the economy should be more closely related to vote choice for those late deciders that are actually paying attention. Additionally, since these voters do seem to be paying attention, it may be that, as posited earlier, issue positions simply do not help them to differentiate among the candidates. If they are truly split when it comes to the issues, the state of the economy may serve as a fallback to help make a choice between candidates that they rate fairly comparably on other dimensions.

But given that these high-interest late deciders are actually paying attention, it is interesting that none of the campaign variables has an effect on their choice among candidates. However, since these voters seem to be about as informed and interested as voters who decide much earlier in the campaign, it is unlikely that campaign advertisements and other campaign efforts would provide them with significantly more information than they already possess from other sources.

Among those who decide before the last two weeks of the campaign, the results of the vote choice analysis are largely as one would expect. Vote choice decisions for early deciders are influenced by a host of variables from both the demographic and attitudinal categories, specifically income, race, gender, union status, party identification, issues, and economic evaluations. Somewhat strangely, gender affects the vote choice of campaign deciders in 
a manner contrary to conventional wisdom. The coefficient for the male dummy variable indicates that male campaign deciders are less likely to vote Republican, a strange twist on the gender gap phenomenon. For the most part, though, early deciders react in the ways that we would expect them to.

Overall, therefore, the influences on vote choice vary in logical ways depending on when those individuals made a decision about which candidate to support in the race. Early deciders vote based on demographic and behavioral factors, long term identifications and beliefs, as well as performance measures that they know or can estimate long before actual date of the election. Meanwhile, late deciders, while all seeming to react to some attitudinal factors, fall into two distinct categories, with low-interest late deciders reacting to demographic and campaign considerations, while high-interest late deciders do not appear to be swayed by either.

\section{Discussion and Conclusion}

Our examination of individuals who reach a decision late in the campaign reveals that this is not the monolithic group that much of the literature (with the notable exception of McAlister 2002) supposes them to be. While these voters do seem to share a weaker party identification and a reduced likelihood of assigning different thermometer rating scores to the candidates, clear differences can be found within the ranks of late-deciders when they are broken into distinct groups based on their level of interest in the campaign. Our results indicate that the first group, low-interest late deciders, does seem to reinforce the negative stereotype of late-deciding voters. While they are, with the exception of race, not demographically distinct from other voters, they are less partisan, less able to differentiate among the candidates, less concerned about the outcome of the election, less likely to pay attention to media coverage of the campaign, less knowledgeable about politics, and less politically active. A smaller, but very distinct group of late-deciding voters, however, look surprisingly like early deciders in terms of their knowledge and attention to the campaign. These high-interest late deciders more closely approximate the idealized view of voters that has taken such a beating in political science over the past 50 years, taking the time to consider all of the evidence before coming to a conclusion. The only major difference between these voters and those who commit to a campaign earlier in the year is that they are less attached to the parties and candidates, and while they are ultimately influenced by their party identification to a significant degree, they would seem to be more willing to give each side a chance to state its case before reaching a conclusion. Therefore, it is important when considering those individuals who do not make a choice until the last two weeks to separate the two groups. 
When looking at how voters decide, the one constant for all groups, not surprisingly, is that party identification plays a significant role in each group's decisions. The magnitude of that effect, however, is much greater for those deciding earlier in the campaign than for those deciding late. For low-interest late deciders, issues are also important determinants of their vote choice, which clearly contradicts the argument put forth by Gopoian and Hadjiharalambous (1994) that those deciding late in the campaign are acting in a nearly random fashion. Instead, they seem to fall back on highly stable shortcuts - party identification and issue positions-which do not require them to pay much attention to current conditions or the characteristics of the particular nominees of each party in the election. High-interest late deciders, on the other hand, are affected by their evaluations of the economy rather than by issue positions. This suggests that these voters, who are certainly subject to having their party identification activated over the course of the campaign ${ }^{9}$, may also be more willing than their more committed colleagues to reward or punish presidents for their performance, regardless of party, and are certainly more likely to pay attention to what is going on at the time of the election. The campaign, however, seems to have no direct impact on these voters. Since they are paying a significant amount of attention to the campaign, but still have not committed themselves to a candidate before the final two weeks of the election, though, this is not truly surprising. Nothing in a campaign ad or candidate speech is likely to dramatically change their perceptions of the choice they face. Finally, early deciders in our study vote in ways that are almost entirely consistent with the broader vote choice literature.

Overall, we believe that the most important finding of this research is that those who decide late in the election are not as easy to differentiate from other voters as the literature has assumed them to be. They are not younger, less educated, or poorer than those who decide earlier in the campaign. Instead, they are individuals who are either seemingly not interested enough in politics to come to a conclusion until forced to, or individuals who are very interested, but not so tied to one side or the other that they do not feel compelled to weigh their options before reaching a decision. Understanding the differences between these groups will hopefully help to clear up the contradictory findings in the previous literature on these voters. 


\section{APPENDIX \\ The Number of LILDs, HILDs, and EDs in the Analysis, by Year, 1988-2004}

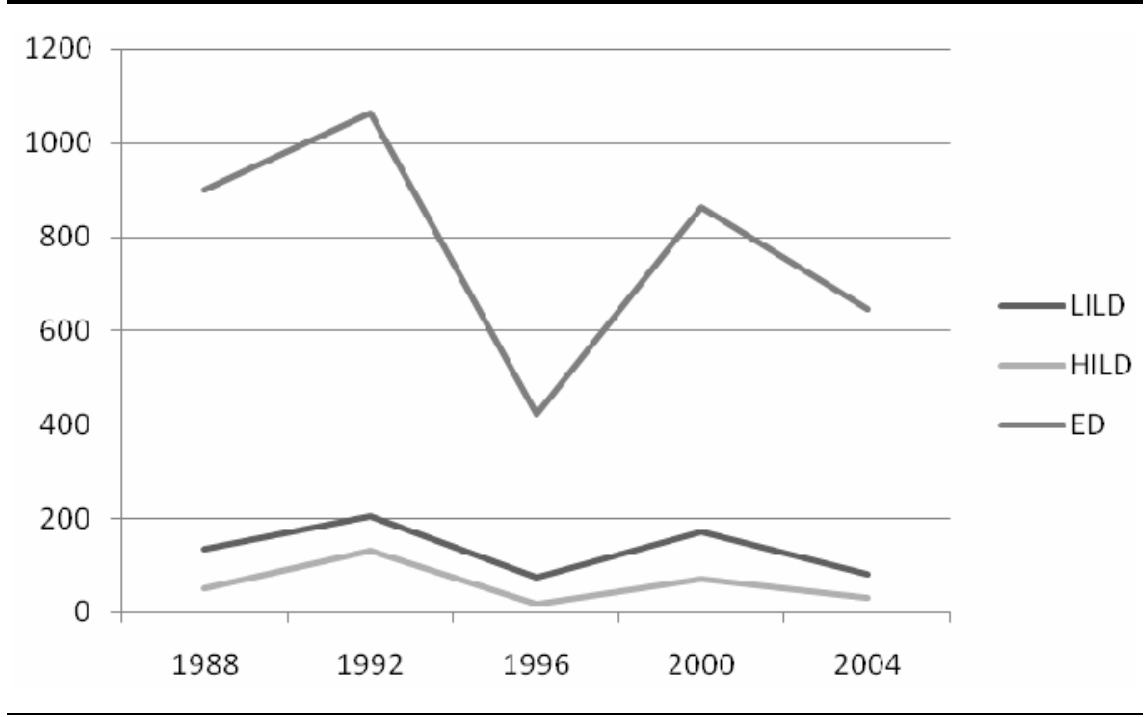

NOTES

${ }^{1}$ Two weeks has been used as a standard cutoff point in the literature since The American Voter, and not coincidentally, that is reflected in the options offered to respondents by the ANES questionnaire.

${ }^{2}$ Television advertising (GRPs) and appearances data are from Shaw (2006).

${ }^{3}$ Battleground rankings data are from Shaw (1999) and from interviews with campaign management from the Bush, Gore, and Kerry campaigns.

${ }^{4}$ Gopoian and Hadjiharalambous (1994) suggest that late deciders turn out to vote because their "social status . . . places external peer and neighborhood pressures . . . to participate in elections despite their lack of an overwhelming interest in the political process" (pp. 74, 76).

${ }^{5}$ Also unresolved is the issue of how partisanship structures vote choice for late deciders. It is possible that late deciders are cross-pressured, and that they tend to vote according to their party identification because they receive campaign information that resolves the pressure and activates their partisanship. On the other hand, if late deciders are not using the media, it would be impossible for activation to take place; so in essence late deciders would pass through the campaign season without exposure to campaign information and would vote based on latent party identification.

${ }^{6}$ Given our new division of the sample of late deciders into High Interest Late Deciders and Low Interest Late Deciders, it would be helpful to revisit the descriptive statistics (first presented on page 2) on time of decision in the National Election Studies for voters in the 1988-2004 presidential elections. Roughly twenty percent of the pooled 
sample reported deciding in the last two weeks of the campaign (our definition of a late decider). When the overall sample is further divided to account for level of interest, 6 percent are HILDs and 14 percent are LILDs. The percentage of HILDs ranges from 3 percent in 1996 to 9 percent in 1992. The percentage of LILDs ranges from 11 percent in 2004 to 16 percent in 2000. For a year by year breakdown, see Appendix A.

${ }^{7}$ Two of these variables require some explanation. Issue distance is the mean of the absolute value of the difference between each respondent's self placement on a series of issues and the mean placement of the entire sample of that candidate on those same issues. This allows us to avoid the potential endogeneity of having the individual respondent both define the candidates' positions and present their own choice between the candidates. The economic evaluation measure asks respondents to rate the performance of the economy over the prior year, scaled so that a higher score is beneficial to the Republican candidate and a lower score is beneficial to the Democratic candidate. Since the evaluation of the economy is taken from the pre-election sample and the vote choice measure from the post-election sample, this also limits the potential endogeneity of this relationship, particularly among late deciders who, by definition, had largely not yet chosen a candidate at the time they were asked to rate the economy.

${ }^{8}$ While we estimate this model separately on the three subsamples (HILDs, LILDs, and EDs), it is possible that the three sets of parameter estimates may not be statistically indistinguishable. To test for this possibility, we performed a "Chow Test" analogue for logit models (DeMaris, 2004). Our results suggest that the estimates for the three subsamples are statistically different than those for a combined sample with $\mathrm{P}<.001$. The results of the test are available from the authors upon request. However, a similar analysis breaking early deciders into high and low interest groups found few differences between the high and low interest groups, such that for ease of comparison we have decided to compare to these voters as one group, rather than breaking them up.

${ }^{9}$ See Finkel (1993).

\section{REFERENCES}

Alvarez, Michael, and Jonathan Nagler. 1998. When Politics and Models Collide: Estimating Models of Multi-candidate Elections. American Journal of Political Science 42:55-96.

Ansolabehere, Stephen, and Shanto Iyengar. 1995. Going Negative: How Attack Ads Shrink and Polarize the Electorate. New York: The Free Press.

Berelson, Bernard R., Paul F. Lazarsfeld, and William N. McPhee. 1954. Voting. Chicago: University of Chicago Press.

Box-Steffensmeier, Janet M., and David Kimball. 1999. The Timing of Voting Decisions in Presidential Campaigns. Presented at the Annual Meeting of the Midwest Political Science Association, Chicago, Illinois, April 15-18.

Campbell, Angus, Philip E. Converse, Warren E. Miller, and Donald E. Stokes. 1960. The American Voter. New York: Wiley.

Campbell, James E. 2000. The American Campaign: U.S. Presidential Campaigns and the National Vote. College Station: Texas A\&M University Press.

Chaffee, Steven H., and Sun Yuel Choe. 1980. Time of Decision and Media Use During the Ford-Carter Campaign. Public Opinion Quarterly 44:53-69.

DeMaris, Alfred. 2004. Regression With Social Data: Modeling Continuous and Limited Response Variables. Hoboken, NJ: John Wiley \& Sons. 
Finkel, Steven E. 1993. Reexamining the 'Minimal Effects' Model in Recent Presidential Campaigns. Journal of Politics 55:1-21.

Flanigan, William H., and Nancy H. Zingale. 1994. Political Behavior of the American Electorate. Eighth Edition. Washington, DC: Congressional Quarterly Press.

Fournier, Patrick, Richard Nadeau, André Blais, Elisabeth Gidengil, and Neil Nevitte. 2004. Time-of-Voting Decision and Susceptibility to Campaign Effects. Electoral Studies 23:661-681.

Gopoian, J. David, and Sissie Hadjiharalambous. 1994. Late-Deciding Voters in Presidential Elections. Political Behavior 16:55-78.

Kessel, John H. 1968. The Goldwater Coalition: Republican Strategies in 1964. New York: Bobbs-Merrill.

Lazarsfeld, Paul F., Bernard R. Berelson, and Hazel Gaudet. 1948. The People's Choice. New York: Columbia University Press.

Markus, Gregory B. 1982. Political Attitudes during and Election Year: A Report on the 1980 NES Panel Study. American Political Science Review 76:538-560.

McAllister, Ian. 2002. Calculating or capricious? The new politics of late deciding voters. In Do Political Campaigns Matter?, eds. David M. Farrell and Rüdiger SchmittBeck. London: Routledge.

Miller, Warren E., Donald R. Kinder, Steven J. Rosenstone, and the National Election Studies. 1999a. National Election Studies, 1992: Pre-/Post-Election Study [dataset]. Ann Arbor: University of Michigan, Center for Political Studies [producer and distributor].

Miller, Warren E., and the National Election Studies. 1999b. National Election Studies, 1988: Pre-/Post-Election Study [dataset]. Ann Arbor: University of Michigan, Center for Political Studies [producer and distributor].

National Election Studies, The. 1996. The 1996 National Election Study [dataset]. Ann Arbor: University of Michigan, Center for Political Studies [producer and distributor].

National Election Studies, The. 2000. The 2000 National Election Study [dataset]. Ann Arbor: University of Michigan, Center for Political Studies [producer and distributor].

National Election Studies, The. 2004. The 2004 National Election Study [dataset]. Ann Arbor: University of Michigan, Center for Political Studies [producer and distributor].

National Election Studies, The. 2006. The Race to 270: The Electoral College and the Campaign Strategies of 2000 and 2004. Chicago: University of Chicago Press.

Shaw, Daron R. 1999. The Methods Behind the Madness: Presidential Electoral College Strategies, 1988-96. Journal of Politics 61:893-913.

Whitney, D. Charles, and Steven B. Goldman. 1985. Media Use and Time of Voting Decision: A Study of the 1980 Presidential Election. Communication Research 12:511-529. 